\title{
CRABP2 Gene
}

National Cancer Institute

\section{Source}

National Cancer Institute. CRABP2 Gene. NCI Thesaurus. Code C104924.

This gene plays a role in retinoic acid binding. 